\title{
Students' Experience of Translation Tool Use In Language Learning
}

\author{
Roswani Siregar*, Ferry Safriandi**, Eka Umi Kalsum*, Syahron Lubis**** \\ * Department of Management, Universitas Al Azhar, Medan, Indonesia \\ *** Department of Accounting, Universitas Al Azhar, Medan, Indonesia \\ **** Department of Linguistics, Universitas Sumatera Utara \\ DOI: $10.29322 /$ IJSRP.11.10.2021.p11811 \\ http://dx.doi.org/10.29322/IJSRP.11.10.2021.p11811
}

\begin{abstract}
The purpose of this study is to identify the online translation tool use among the students of higher education and to raise their awareness on translation procedures in doing such work. The results of questionnaire reveals the experience related to intensity and purpose of Google Translate and translation procedures was conducted in classroom setting. This study attended by 37 students who are beginner to subject of translation. The teaching procedures divided into four sessions. The first and the second session revealed the student experience on using Google Translate. The second and three sessions introduce the source text-reading and pretranslation editing. Because of translation is metacognitive activity, the students also encourage to takes note, discuss and ask the question in completing their works. In the final session, the trainer introduced a brief theory of translation to raise their awareness of importance of translation theories in enhancing their ability to improve the machine assisted translation result.
\end{abstract}

Keywords:

Index Terms- translation, procedure, language learning, online, google

\section{INTRODUCTION}

As technology develops, translation works is also involved the use of technology and more stick to it. Pym and Jose (2006) stated, technology extends human capacities, some of them affect our communications, and thus translation. Pym added, in the fields of electronic technologies, translators are less commonly employed to translate whole texts, as one did for the books with concordances. Thus, translations like the production of common text, become more like a database, a glossary, and a set of electronic tools, not complete definitive source text.

Google is one of the major providers of Internet-based information search services. In addition to various other services offered by Google, one of the most popular services is Google Translate. The translator engine from Google then becomes a solution that helps millions of people translate text or web pages from one language to another automatically. Today, Google Translate is available in more than 103 languages in the world, one of which is from English into Indonesian and vice versa.

One of the most widely used translation engine is Google Translate. Its service enable the students to translate the text of various languages into Indonesian or vice versa. However, almost of students unrealize that the translation of Google Translate is classified as a pre-translation that needs for human intervention. The results of Google Translate sometimes misleading (Susanto, 2017:33).

In this article, based on student's experience on using Google-Translate, we focus on observation of student's interest and their reliability on Google-Translate result, and how the brief translation theory raise their awareness of importance of translation skill and encourage them to attend the translation training in the future.

\section{LITERATURE REVIEW}

II.1 The Importance of Translation Skill and Teaching

In globalized world, translation enable peoples from different language to communicate effectively. It is all around us from families, universities, hospitals, courts, and clinics, to business meetings. Translation is a bridge for spreading of information, knowledge, invention and ideas. In pedagogy, translation is a fundamental basis for language learning. Translation can be used to aid learning, practise what has been learned, diagnose problems, and test proficiency. Translation encourage the students to recognize the relation of new knowledge to existing knowledge noticing and language awareness, and highlights the differences and similarities between the new and existing language. 
In the half of the 20th century, translation study became crucial in language teaching and learning. The pragmatic and systematic approach was used in translation study (Schaffner, 1998). The EFL students beneficial from it and expand their vocabulary, develop their style, improve their understanding of how languages work and monitor and improve the comprehension. The EFL students showed positive attitude on specif purpose translation course (Siregar, 2017:1)

Internet and latest communication technology development has increased cultural exchanges between nations. It also benefit for students who study translation to find the related material in doing translation activities. Technology serves practical techniques that enable them to translate more and waste less. (El-Dali, 2010).

Gerding-Salas (2000) proposed a methodology that consisting of a step-by-step procedure workshop of translation training for undergraduate students. She modelled the workshop activities by collaborating a cooperative activity in sequential procedure. Translation procedure assist the student to comprehend the importance of the faithfulness to the meaning of the source language text being transferred to the target language text. It is based on the Nida and Taber (1974) who suggested to reproduce the nearest equivalent message in the source language into target language.

II.2 Translation Technology

Google Translate is introduced in 2006 and has brought a change to teachers and students perspective related to translation teaching and training. Formerly, the instruction in translation was largerly relied on teacher resourcefulness and the physical availability of parallel and similar texts, today it possible by the advance of communication technology. The free online dictionary and web tools in translation are growing in number and more reliable. Therefore, the traditional teaching models no longer popular in computerconnected classroom. In traditional, students spending more time working on translation practice than computer-connected classroom (Korošec, 2011:5).

However, concerning the effectivenes, Kelly (2005) stated that the new technologies should be collaborate with learning strategies. The integration of technology in learning should be directly to encourage the students in doing practices in order to attain the translation competences. Thus the goal of designing activities for students is to build the translation competence. The translator competence ranging from the cultural knowledge, specialization in particular subject area and self confidence (Siregar, 2017).

Based on their subject and technology, the translation is devided into human translation and machine translation. In the first, the translation process is entirely done by humans or with assistance of computer technology. This type of translation is also known as computer-assisted translation (CAT). While the second is done by human-assisted machines. Thus this kind of translation is also knows as human-assisted translation. Technology offers the translation memories (TMs), a program to build databases of source-text and target-text that can be re-used anytime. This tool saves translator time in deal with high repeated terms and phrases in translation process. Inarguable, translation memories is a great aid for translation services that cutting down the time and increasing the productivity (Korošec, 2011:1).

Google Translate (GT) is one of popular translation machines across the internet. GT use statistical machine translation (MT) platform that currently provides automated translations over 108 languages. According to Google official blog, the launching Google Translate aimed to break language barriers and to make the world more accessible. Now, more than 500 million people use Google Translate. Google Translate translates more than 100 billion words per day. Ninety-two pecent of users are outside of the United States. GT is more than a webpage, that allows the user to access Google Translate offline. By download the Android app, the users can get a rough translation of more than 108 different languages on their smartphone without using any data. Google give the chance for user to improve the translation. When the user find inaccurate or error translation in Google Translate, they can report it to the Google Translate community. Veritas (2009) argued that the GT's success is to a large extent predicated on its statistical approach, which has proven to produce better results than the previously supported rule-based linguistic systems.

\section{II.3 Translation Procedures}

Vinay and Darbelnet (1995:31-34) proposed the taxonomy of translation procedures used to deal with incompatibilities between SL and TL structures distinguishes two major methods of translation. The first procedure is direct translation that characterized by resemblence of word by word translation from source language to the target language. The direct translation includes borrowing, calque and literal translation. The second procedure is oblique translation that characterized by the translator interpretation, such as summarizes and produce the explicit contents of the original text into target language. Oblique translation includes transposition, modulation, equivalence, and adaptation translation procedures.

Borrowing is the simplest procedure in translation. This procedure is used for absence of text in the target language that related to metalinguistic. Borrowing is frequently appears by new technologies and its terminology. Calque is similar to borrowing in which the target language (TL) borrows an expression form the source language (SL) by translating literally each of the original elements. This publication is licensed under Creative Commons Attribution CC BY. 
Literal translation is direct transfer of a text from SL into a grammatical and meaningful text in TL. Generally, this procedure is used when translator adhering the source to the linguistic rules of the TL. Transposition is replacing one word class with another without changing the meaning of the text. It can be applied intralinguistically, i.e. within a particular language. Modulation means change the form of the message through a change in perspective. This procedure is required in contexts where a literal or transposed translation still sounds unidiomatic or awkward in the TL, despite being a grammatically correct utterance. Equivalence, also known as reformulation, produces an equivalent text in the target language by using completely different stylistic and structural methods. Adaptation is used when the type of situation referred to by the SL message does not function in the TL culture. In such cases the translator must recreate a situation that can be regarded as more or less equivalent (Waliński, 2015:57).

\section{METHOD}

\subsection{The Purpose of the Study}

The purposes of this study are:

a. To identify the intensity use, purpose and reliability of Google Translate by observing the students' experience in using Google Translate.

b. To implement the translation procedures and raise the students awareness on importance of translation theory for better understanding in doing translation work.

\subsection{Research Design}

Type of study. This qualitative research conducted by observation to student's experience in using Google Translate and their awareness on benefit of translation skill for academic achievement.

Data Collection. The data was collected by a questionnaire that consisted of 8 questions to find out the student's experiences, interest, and opinion concerning the translation.

Data analysis. A short article selected from internet page is set as source text. The student assigned to provide its translation in Indonesian by using Google Translate. Before submitting the final translation to instructor, the students assigned to made editing to Google Translate result. The instructor also provide her version as comparison in analysis. Based on the comparison, the translation analysis is made by following steps: 1) Collecting samples 2) Identifying and classifying errors 3) Sorting errors 4) Explaining error 5) and correcting errors.

Interview and notes. In the end of course, the researchers randomly interviewed the participants that lasted approximately 10 minutes. Course Procedures. This study adopted some of Gerding-Salas (2000) teaching procedures, ranging from the material selection to student assignment procedure.

\subsection{Participants}

This short course attended by 37 students of Management Department of Al-Azhar University, Medan in October 2019. The course was done in classroom setting with 4 sessions.

\section{FINDINGS AND DISCUSSION}

\section{IV.1. Student Experience}

A. Students purpose of using Google Translate

In the first session, student assigned to fill out the questionnaire. It took 15 minutes, including the trainer explanations about the purpose and objectives of the training. The questionnaire reveal the student experience and interest in using Google Translate.

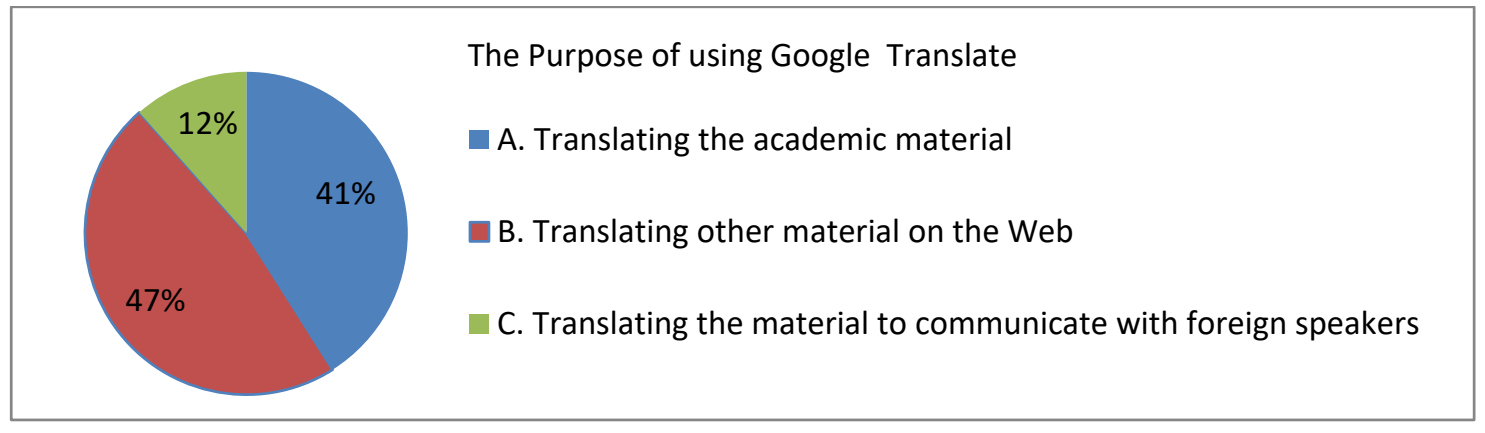

Figure 1. The Purpose of Google Translate

This publication is licensed under Creative Commons Attribution CC BY.

http://dx.doi.org/10.29322/IJSRP.11.10.2021.p11811 
Concerning the purpose Google Translate, 32 respondents use it to translate the academic material; while all of respondents admit to use it to translate other material on the web, and 16 of them use it to communicate with foreign speakers. As reported by Sujarwo (2020:239), EFL students use Google Translate not only to translate the reading materials itself, but also to check the pronounciation. The students use the internet to dig the academic material. Apparently, the students prefer to research a topic on the internet rather than go to the library.

Google translate is useful tool to bridge the barrier of language. Most of students use Google Translate for English into Indonesian. The second is Indonesian into English. Interestingly 18\% of respondent use Google Translate for Indonesian into other languages such as Arabic, Japanese, Chinese and German. The main reason for its use is to help them to communicate via social media.

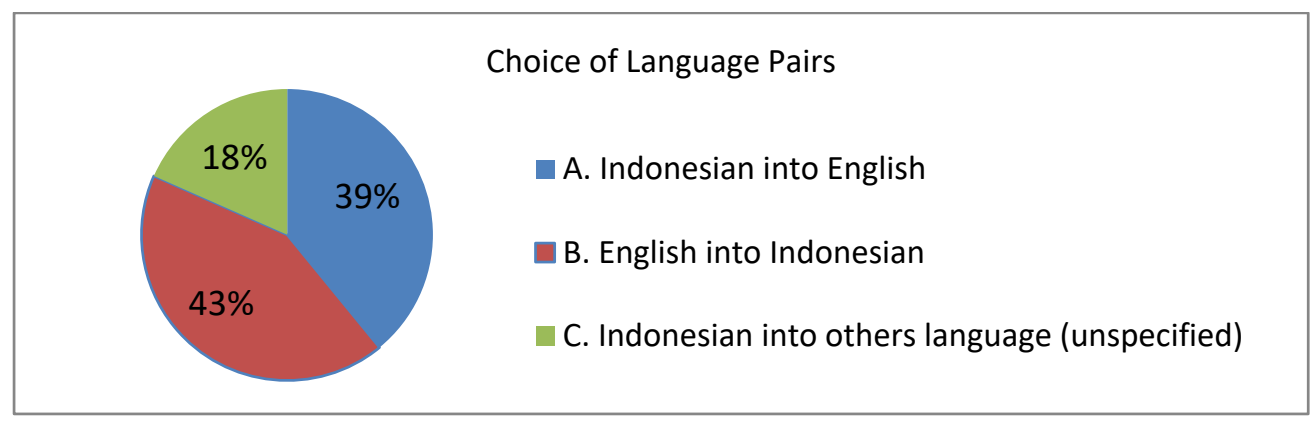

Figure.2 Choice of Language Pairs

As Herlina et.al (2019:72) argued, students found this tool was useful to understand the reference books. Moreover, students are also use Google translate in translating web content, such as news, song lyrics, product specifications, etc. They also use Google Translate while communicating with other language speakers via social media.

B. Google Translation Reliability

Google Translate offers the powerful online translation tools available. It is free and fast. A human translator cannot compete with the speed nor, as a result, the quantity of translations that Google Translate is able to perform translation of 5000 words in few seconds. Google Translate uses a statistical method to form an online translation database based on language pair frequency. Google Translate frequently produces translations with grammatical errors. Allué (2017:67) categorized the errors at a lexicogrammatical, syntactic, pragmatic and punctuation level. This is due to the fact that GT based on language pair frequency that does not take into account grammatical rules. However in its latest update, Google announced Zero-Shot Translation with Google's Multilingual Machine Translation System, which avoids clumsy translation of individual language pairs by translating input phrases to distributed vector representations of their supposed meanings independently of language(s) in question.

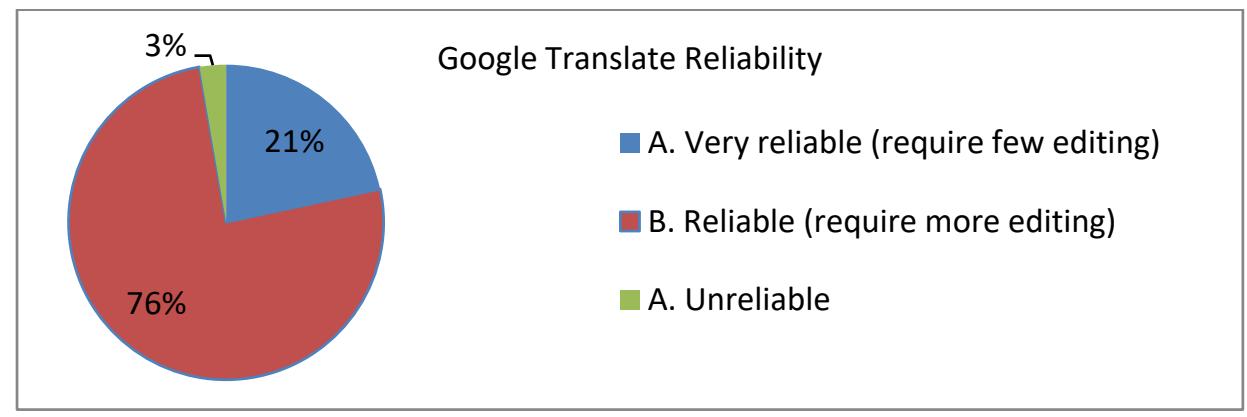

Figure 3. Google Translate Reliability

When it comes to reliability, $21 \%$ of respondents allege that Google Translate is very reliable and just require few editing. Most of them $(76 \%)$ believe it reliable, thus requires more editing. The rest (3\%) state it is unreliable. The reason for unreliable is for it is resulted mistranslation. The reliability of Google translation also reported by Lyons (2016:51) where over 85\% of Thai students were satisfied on its result. However most of students were not doing post-translation editing on Google translation results.

IV.2 Implementation of Translation Procedures

A. Pre-Translation

The prepared material to be translated (source text) were distributed to students. The text derived from internet. The instructor provide the general subject by taking account to degree of difficulty of the texts and participants experience. The students should read the whole text twice: The first reading will be comprehensive and general. The second reading must be a "deep" reading, placing This publication is licensed under Creative Commons Attribution CC BY. 
ISSN 2250-3153

emphasis on items where translation problems may appear. After scan reading of the material, the students assisted to identify the source, the norm, the type of text, the register, the style and the readership of the text selected. The students assigned to translate material using Google Translate by enter text into Google Translate and set the target language.

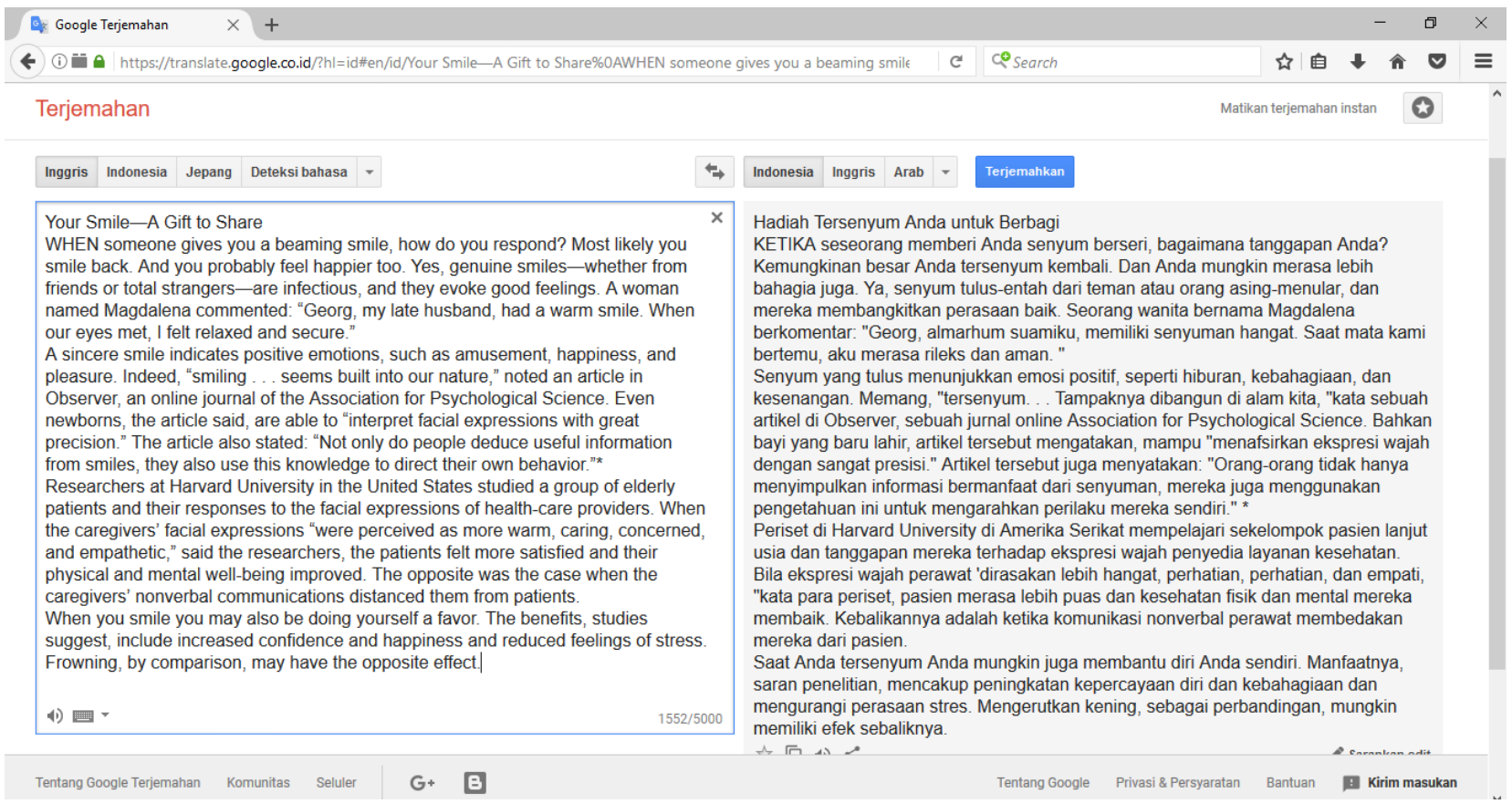

Figure 1. The Google Translate result

B. The editing session

The student assigned to divide source text and target text into separated paragraphs and lines. In this session the students and the teacher follow the reading of each text attentively. As a monitoring activity, everybody should feel free to stop the reading at the end of a given sentence and have the reading of the segment repeated.

Table 1. Source Text and Target Text in Editing Session

\begin{tabular}{|c|c|c|}
\hline Par & Source Text & Target Tex by GT* \\
\hline & Your Smile_-A Gift to Share & Senyum Anda - Hadiah untuk Berbagi \\
\hline \multirow[t]{3}{*}{1} & $\begin{array}{l}\text { WHEN someone gives you a beaming smile, how } \\
\text { do you respond? }\end{array}$ & $\begin{array}{l}\text { KETIKA seseorang memberi Anda senyum berseri, } \\
\text { bagaimana tanggapan Anda? }\end{array}$ \\
\hline & $\begin{array}{l}\text { Most likely you smile back. And you probably } \\
\text { feel happier too. }\end{array}$ & $\begin{array}{l}\text { Kemungkinan besar Anda tersenyum kembali. Dan Anda } \\
\text { mungkin merasa lebih bahagia juga. }\end{array}$ \\
\hline & $\begin{array}{l}\text { Yes, genuine smiles — whether from friends or } \\
\text { total strangers - are infectious, and they evoke } \\
\text { good feelings. (Awake, 2017) }\end{array}$ & $\begin{array}{l}\text { Ya, senyum tulus-entah dari teman atau orang asing-menular, } \\
\text { dan mereka membangkitkan perasaan baik. }\end{array}$ \\
\hline Etc & $\ldots \ldots \ldots \ldots \ldots$ & $\ldots \ldots \ldots \ldots \ldots \ldots$ \\
\hline
\end{tabular}

The students, assisted by the teacher, analyze the translation strategies and procedures used, and discuss the reasons taken into account in the choice of each analyzed criterion. If the topic is completely unknown to the students, they should consult complementary literature in internet. As Newmark states, "translation is for discussion" (Newmark, 1995). Students should then be encouraged to take notes and discuss the difficulties that arising from this analytical reading of each one of the different versions proposed. when the situation warrants comments, suggestions, questions, contributions, etc. The students have to "defend" their work against criticism.

After students hand in the final version of their revised and post-edited segments, which have already been amended in the fourth coloum (as shown above) The work must be prepared in two coloumns by return text into initial paragraphs. The instructor provides a final revision (second post-edit), gives formative evaluation and makes comments, and analyzes failures and weaknesses in the process of translation. 
C. Translation Procedures Analysis

The translation procedure analysis was conducted from the point of view of Vinay and Darbelnet's (2000). Based on translation procedure analysis, the result of Google Translation versus Human Trnslation is presented in following table:

Table 3. Result of Translation Procedure Analysis

\begin{tabular}{llc|c}
\hline \multicolumn{2}{c|}{ Procedures } & Google Translate Translation & Natural Translation \\
\hline Direct translation & Borrowing & 1 & 1 \\
& Calque & - & 6 \\
\hline Lblique translation & Transposition & 16 & 8 \\
& Modulation & - & 2 \\
& Equivalence & - & \\
& Adaptation & - & \\
\hline
\end{tabular}

The translation process of translator machine is different from manual translation. Google Translate is based statistical machine translation. As machine translation, Google Translate scans a large collection of text, which contains source text and the corresponding target language, then analyzed by statistical formula. The results of the analysis provide the data that can be used as a basis to translate. It gathers as much text that seems to be equivalent between two languages.

Direct translation is common with Google Translate and often results. It is not surpising that the type of Google-Translate translation is literal. When met the complex e text, as well as any context that unsuitable to be interpreted without a the adequate knowledge of the language, it resulted the awkward translation. According to Siregar (2017:323) in translation teaching, the literal translation can avoided by direct students' attention away from grammar and lexis towards whole-text and translation-task.

Table 3. The comparison of Google translation result and manual translation.

\begin{tabular}{lll}
\hline Source Text & Target Tex by GT* & Suggested Translation \\
\hline Your Smile-A Gift to Share & Senyum Anda - Hadiah untuk Berbagi & Tersenyumlah - Itu Hadiah Terbaik
\end{tabular}

In suggested translation, the transposition occurs when rendering a translation for a particular segment of the text that requires the translator to break the formal correspondence between surface structures functioning in Source language and target language.

\section{CONCLUSION}

Everyone teaches technology in the hope and belief that it will make translating more efficient, in one way or another. However, few curricula bother to include touch-typing, which is the basic way translators can make their work faster. As machine translator, GoogleTranslate is the vast translation-machine used world-wide. Neverthless, the online translation machine such Google Translate bring the significant benefit to users, particularly students of non-native English speakers to dig the academic material and web content in English and other languages.

Although Google has integrated Google Neural Machine Translation system to improve quality of translations by enabling their systems to take into consideration the source words and phrases, and broader context. The results of analysis revealed that GoogleTranslate provides a literal and word-for-word translation that sometimes show the grammatical mistakes and unmacthed-structured that lead to lost translation. By identify the students experience and implementation of translation procedure analysis, the students realised the importance of translation theory enhance their ability and the needs of human involvement for better translation result.

Here comes the most crucial step for your research publication. Ensure the drafted journal is critically reviewed by your peers or any subject matter experts. Always try to get maximum review comments even if you are well confident about your paper. 


\section{ACKNOWLEDGMENTS}

This research was partially supported by Ristekbrin/Ristekdikti. We also thank to our colleagues who provided insight that assisted the research.

\section{REFERENCES}

[1] Allué, B.R. (2017). The Reliability And Limitations Of Google Translate: A Bilingual, Bidirectional And Genre-Based Evaluation. Entreculturas 9. pp.6-80.

[2] Awake!.(2017). Your Smile - A Gift to Share. (Retrieved from https://wol.jw.org/en/wol/d/r1/lp-e/102017006

[3] El-Dali H.M. (2010) Towards an understanding of the distinctive nature of translation studies. (Retrieved from http://ac.elscdn.com/S2210831910000056/1-s2.0-S2210831910000056-main.pdf?_tid=22aac0cc-7006-11e7-bdac00000aab0f6b\&acdnat $=1500855911 \_$_c7b87b3be59713ab2e68a6870a669c2

[4] Gerding-Salas, C. (2000). Teaching Translation: Problems and solutions. Translation Journal 4(3). http://translationjournal.net/journal/13educ.htm

[5] Herlina, N., Dewanti, R., \& Lustiyantie, N. (2019). Google Translate As An Alternative Tool For Assisting Students In Doing Translation : A Case Study At Universitas Negeri Jakarta, Indonesia. BAHTERA: Jurnal Pendidikan Bahasa Dan Sastra, 18(1), 70-78. https://doi.org/10.21009/BAHTERA.181.06

[6] Korošec M. (2011). The Internet, Google Translate and Google Translator Toolkit. (retrieved from http://lodel.irevues.inist.fr/tralogy/index.php?id=113

[7] Lyons, S. (2016). A Survey of The Use of Mobile Technology And Translation Tools by Students At Secondary School In Thailand. Payap University Journal, 26(1), 35-57. https://doi.org/10.14456/pyuj.2016.1

[8] Newmark, Peter. (1995). A Textbook of Translation. Library of Congress Cataloging-in - Publication Data. Oxford University Press ELT, 2011. Translation in language teaching and learning. (Retrieved https://oupeltglobalblog.com/2011/10/20/translation-in-language-teachingand-learning/

[9] Nida, Eugene A, \& Taber, Charles R. (1974). The Theory and Practice of Transalation. UBS: Leiden

[10] Pym A. \& Jose R. (2006). Technology and translation. (retrieved from http://www.intercultural.urv.cat/media/upload/ domain317/arxius/Technology/translationtechnology.pdf

[11] Schaffner, C. (1998). Qualification for Professional Translators. Translation in Language Teaching Versus Teaching Translation. Manchester. St. Jerome publishing.

[12] Siregar, Roswani (2017). Teaching Specific Purpose Translation: Utilization of Bilingual Contract Document as Parallel Corpus. English Language Teaching; Vol. 10 (7), pp.175-182. http://doi.org/10.5539/elt.v10n7p175

[13] Siregar, Roswani (2017). Designing Course: An Initial Approach To Translation Teaching. International Journal of Scientific \& Technology Research, Vol. 6 (9), pp 321-324.

[14] Sujarwo, S. (2020). Students' Perceptions of Using Machine Translation Tools In the EFL Classroom. Al-Lisan: Jurnal Bahasa (e-Journal), 5(2), 230-241. https://doi.org/10.30603/al.v6i2.1333

[15] Susanto, R.D. (2016). Students' Attitudes Toward The Use Of Google Translate. Theses. English Language Education Program, University of Kristen Satya Wacana. Retrieved from https://repository.uksw.edu/bitstream/123456789/14459/2/T1_112013007_Full\%20text.pdf.

[16] Veritas (2009). Statistical Machine Translation and Example-based Machine translation (retrieved from http://www.proz.com/translationarticles/articles/2483/1/Statistical-Machine-Translation-and-Example-based-machine-Translation).

[17] Vinay, Jean-Paul and Jean Darbelnet (1995) : Comparative Stylistics of French and English, a Methodology for Translation, translated and edited by Juan C. Sager and M.-J. Hamel, Benjamins Translation Library, vol. 11, Amsterdam/Philadelphia, John Benjamins, XX + 358 p.

[18] Waliński J.T. (2015) Translation Procedures. University of Łódź. pp.55-67.Retrieved from https://idoc.pub/documents/walinski-2015translation-procedurespdf-2nv8o3w0qylk

\section{AUTHORS}

First Author - Roswani Siregar,

Senior Lecturer at Department of Management, Unviersitas Al Azhar, Medan

Email: roses_air@yahoo.com

\section{Second Author}

Syahron Lubis, Department of Linguistics, Universitas Sumatera Utara

\section{Third Author}

Ferry Safriandi, Department of Accounting, Universitas Al Azhar, Medan

\section{Fourth Author}

Eka Umi Kalsium, Department of Management, Universitas Al Azhar, Medan

This publication is licensed under Creative Commons Attribution CC BY.

http://dx.doi.org/10.29322/IJSRP.11.10.2021.p11811 